\title{
An analysis of students'grammatical errors in translating Indonesian recount text into English made by the first grade of senior high school
}

\author{
Nilam Puspita Sari ${ }^{1}$, Gede Eka Putrawan ${ }^{2}$, Rafista Deviyanti ${ }^{3}$ \\ FKIP UniversitasLampung, Jl. Prof. Dr. SoemantriBrojonegoro No.1, Rajabasa, Bandar \\ Lampung ${ }^{1,2,3}$ \\ ${ }^{1}$ nilampuspitasari1206@gmail.com
}

\begin{abstract}
This research was aimed at finding out types of grammatical errors and investigating types of errors that were most and least frequently made by students based on Communicative Effect Taxonomy that were found in students' recount text translation as well as figuring out the causes of those errors. The subjects of this research were the first grade students of SMAN 1 Pringsewu in the academic year 2020/2021. This research adopted a descriptive qualitative method by using a translation task and questionnaire as the instruments. The results revealed that the students committed all error types in terms of Communicative Effect Taxonomy: global error and local error. Local errors were more dominating than global errors. The possible causes of those errors were problems in the target language, mother-tongue interference, lack of eagerness to learn the target language, lack of confidence, and the absence of error feedback from the teacher. This suggests that the student's knowledge of English grammar was still low. Therefore, the English teacher is expected to solve it by providing appropriate teaching methods and materials to minimize the errors.
\end{abstract}

Keywords:Error Analysis, Communicative Effect Taxonomy, Translation

\section{INTRODUCTION}

Learning English as a foreign language (EFL) in Indonesia often makes students face some difficulties. They are required to have good knowledge of four basic language skills such as listening, reading, speaking, and writing (Khoirunida, 2019). Writing is deemed the most difficult language skill by students (Dang, 2019) because when writing a text they are required to pay careful attention to five general components of the writing process which include content, form, grammar, style, and mechanics (Kumala, Aimah, \& Ifadah, 2018). However, writing in English is not an easy matter that needs little effort for students since the linguistic structures of English differ from that of their first language (L1)(Dang, 2019). Thus, they have more possibility to make grammatical errors when writing in English.

Grammar is a system of rules governing the conventional arrangement and relationship of words in a sentence that becomes meaningless if the two other dimensions, semantics and pragmatics, are absent (Brown, 2001).Making errors is common in the learning process. In learning a second or foreign language, people cannot learn the language without making errors first (Dulay, Burt, \& Krashen, 1982). 
Writing in English is completely different from writing in Indonesian. In Indonesian, there are no tenses, a verb appears in the same form at all times, whereas English has a very strict order and rule to follow when constructing sentences according to tenses. Thus, students misuse verbsin writing in English since tenses are not a feature in Indonesian. Although they have been learning English since they were in elementary school, they still find it hard to translate from Indonesian into English (Khoirunida, 2019) especially when translating past events into English (Anjarani \& Indahwati, 2019). In addition, Koman, Hartono, \& Yuliasri, (2019)found that students made grammatical errors when translating a text from Indonesian into English in terms of word choice, verb changes, and punctuation.Kumala et al's. (2018) findings suggest that these errors were made unconsciously and students have reasons to make such errors, e.g. carelessness, first language interference, and translation.

In this study, the researcher conducted an error analysis and used a translation task from Indonesian into English to find out the grammatical errors made by students. Moreover, the researcher used an open-ended questionnaire to investigate the possible causes of students' grammatical errors and students' awareness about their errors.By doing this research, it is expected that this research can have significant uses theoretically and practically. Theoretically, this research is expected to be used as information to enrich previous research and further research. While, practically, it can be an input for English teachers to minimize students' errors, and for the students, the errors in their translation can be feedback to improve their grammar understanding and minimize their weaknesses in writing.

\section{METHODS}

This research adopted a descriptive qualitative approach to describe and analyze the grammatical errors made by students in translating a text.In this study, the researcher described students'errors in the simple calculation that calculates the errors in percentage forms. Then, those errors were described with each sample of errors qualitatively.In this study, the researcher analyzed and categorized the errors based on Communicative Effect Taxonomy. The population of the research was the first grade students of SMAN 1 Pringsewu in academic year 2020/2021. The researcher selected three students from each ten class as samplewith the total of students were 30 .

In this research, the translation task was used as the instrument to get the data of students' errors. Recount text was the topic of the task. It was about "My holiday in Yogyakarta" which consisted of four paragraphs, with 194 words in 20 sentences. The students translated the text on Quizizzwithin 80 minutes. To get the possible causes of errors, the researcher used an openended questionnaire consisting of 10 questions to look at the possible causes of errors and 20 questions to investigate the students' awareness about their errors.

In analyzing the data of students' errors, the researcher followed some steps, as follows: 1) identifying the errors, 2) classifying the errors, 3) calculating the errors, 4) tabulating the errors, and 5) explaining the errors. The data from questionnaires were analyzedqualitatively by coding and categorizing the data. Then, the data were presented in pie charts to show the frequency of 
the students' different answers to each question. In interpreting, the researcher compared the findings to relevant theories or other research findings.

\section{RESULTS AND DISCUSSIONS}

\section{Results}

As a result, the study elaborated the findings as to the relevant data of the research as the following.

\section{Types of Error Found in Students' Translation}

Concisely, the students committed errors in their translation in the forms of global errors and local errors, which were categorized in terms of Communicative Effect Taxonomy.

\section{Frequencies of Students' Grammatical Errors based on Communicative Effect Taxonomy} To take a case in point concerned with the frequency of each error type are classified in this taxonomy, Table 1 below presents the data.

Table 1.Students' Errors Frequencies based on Communicative EffectTaxonomy

\begin{tabular}{|c|c|c|c|c|}
\hline No. & $\begin{array}{c}\text { Communicative } \\
\text { Effect Taxonomy }\end{array}$ & Component & Frequency & $\begin{array}{c}\text { Percentage } \\
(\%)\end{array}$ \\
\hline \multirow[t]{4}{*}{1} & \multirow[t]{4}{*}{ Global Error } & $\begin{array}{l}\text { Wrong order or major } \\
\text { constituents }\end{array}$ & 4 & $2.6 \%$ \\
\hline & & $\begin{array}{l}\text { Missing and wrong } \\
\text { misplaced sentence } \\
\text { connectors }\end{array}$ & 1 & $0.7 \%$ \\
\hline & & $\begin{array}{lr}\text { Missing } & \text { cues } \\
\text { signal } & \text { obligatory } \\
\text { exceptions } & \text { to } \\
\text { pervasive } & \text { syntactic } \\
\text { rules } & \end{array}$ & - & - \\
\hline & & & 5 & $3.3 \%$ \\
\hline \multirow[t]{5}{*}{2} & \multirow[t]{5}{*}{ Local Error } & $\begin{array}{l}\text { Error in noun and } \\
\text { verb inflection }\end{array}$ & 126 & $82.3 \%$ \\
\hline & & Error in article & 12 & $7.8 \%$ \\
\hline & & Error in auxiliary & 9 & $5.9 \%$ \\
\hline & & $\begin{array}{l}\text { Error in formation } \\
\text { quantifier }\end{array}$ & 1 & $0.7 \%$ \\
\hline & & & 148 & $96.7 \%$ \\
\hline & Total & & 153 & $100 \%$ \\
\hline
\end{tabular}

Table 1 showsthatlocal errors were more frequent than global errorsin terms of Communicative Effect Taxonomy. Meanwhile, the least error made by students was global error. Moreover, the students mostly made errors in noun and verb inflections, while the least error committed by the students was in the formation of quantifier. 


\section{Results of the Questionnaire related to the Causes of Errors}

In this study, there were five possible causes the researcher found based on the results of the questionnaire, and they were problems in the target language, mother-tongue interference, lack of eagerness to learn the target language, lack of confidence, and the absence of error feedback from the teacher.After the questionnaires had been answered, the results of each question are displayed in the form of pie charts that can be seen in the figures below.

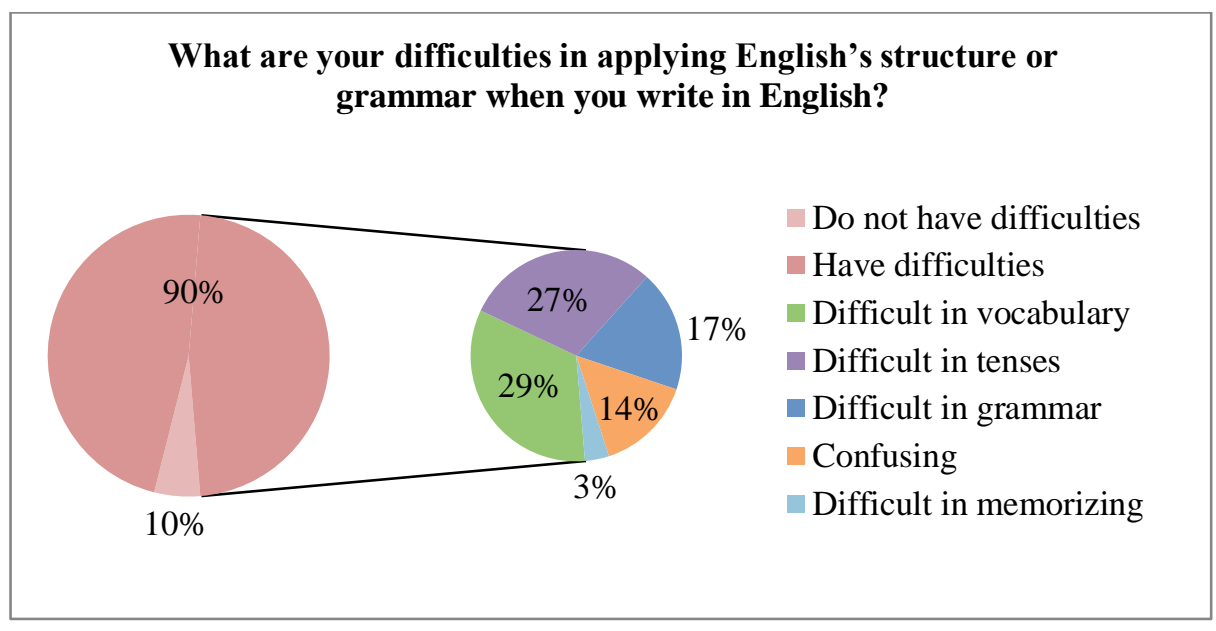

Figure 1. Results of Questionnaire related to Problems in the Target Language.

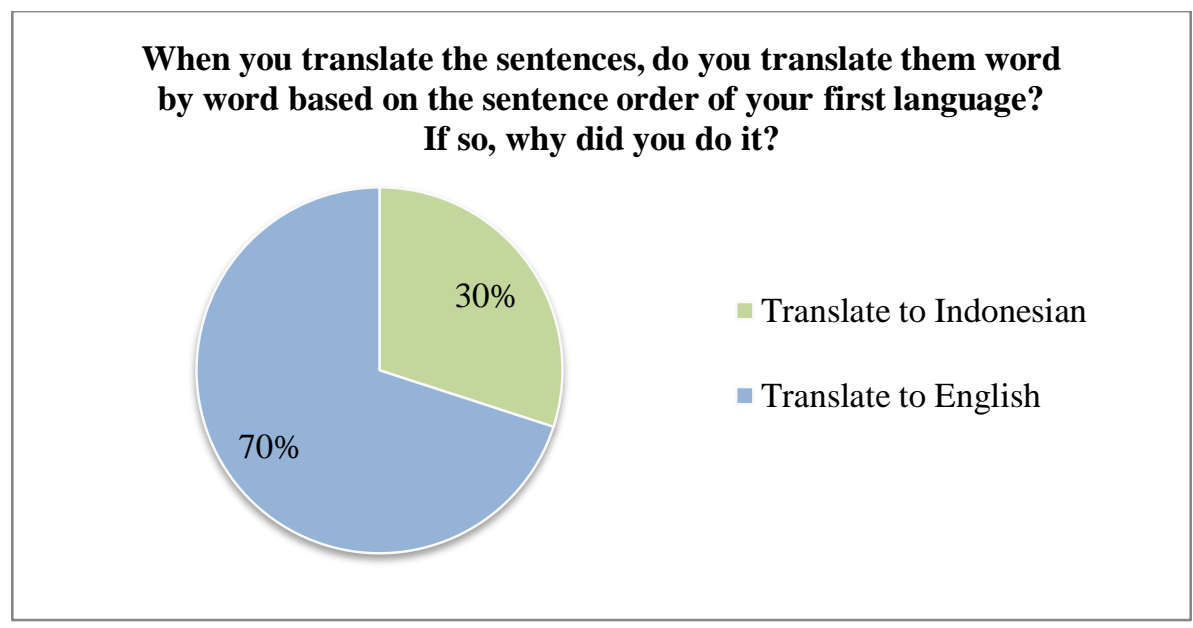

Figure 2. Results of Questionnaire related to Mother-tongue Interference. 


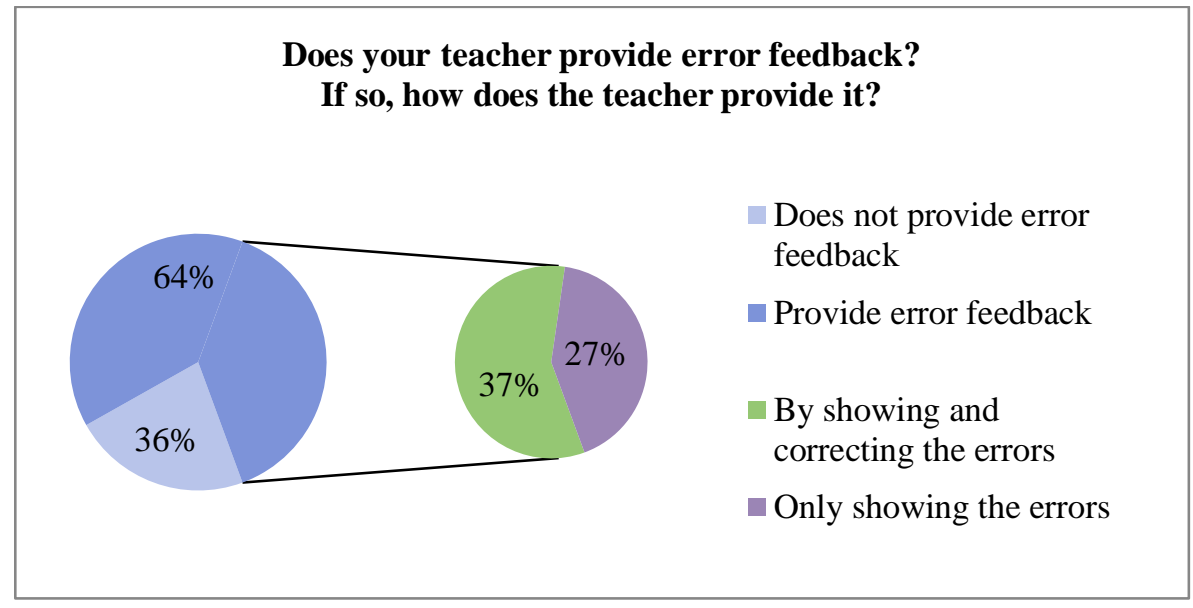

Figure 3. Results of Questionnaire related to the Error Feedback from the Teacher.

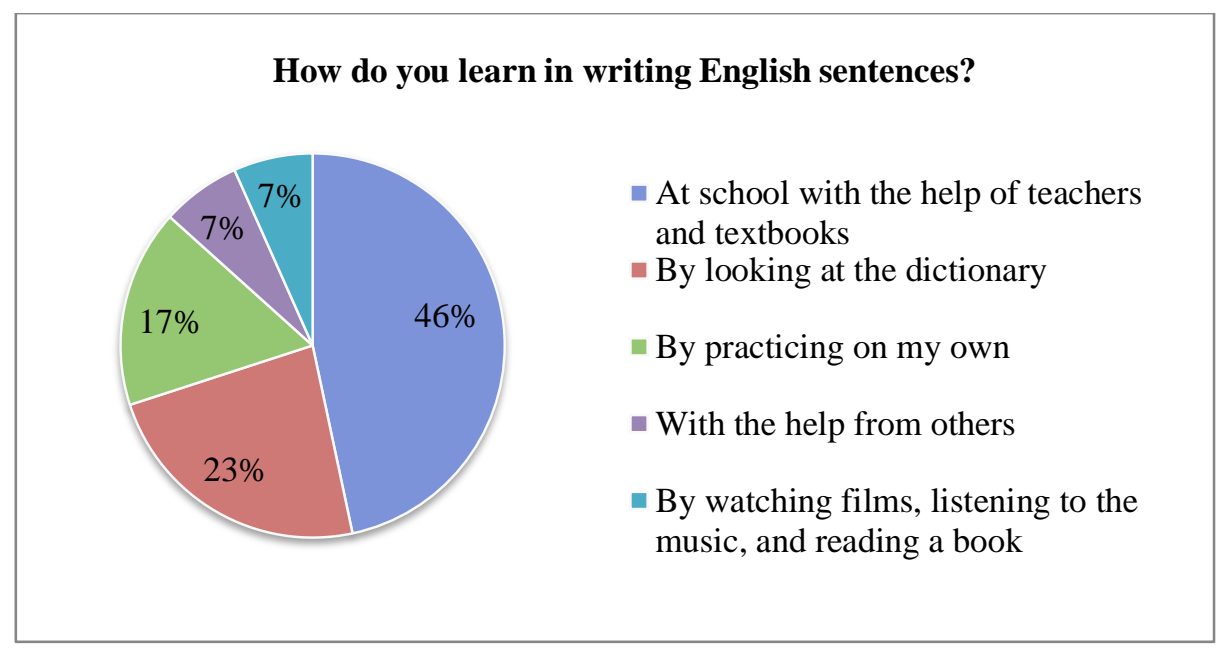

Figure 4. Results of Questionnaire related to the Eagerness to Learn the Target Language. 


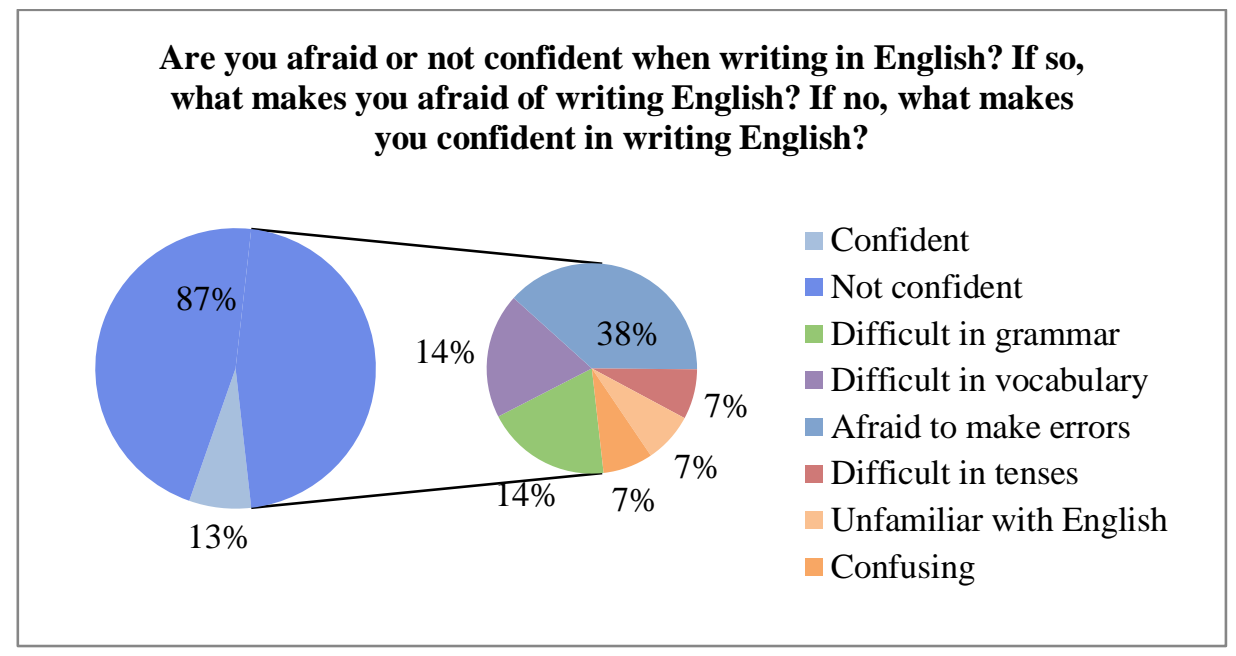

Figure 5. Results of Questionnaire related to Confidence.

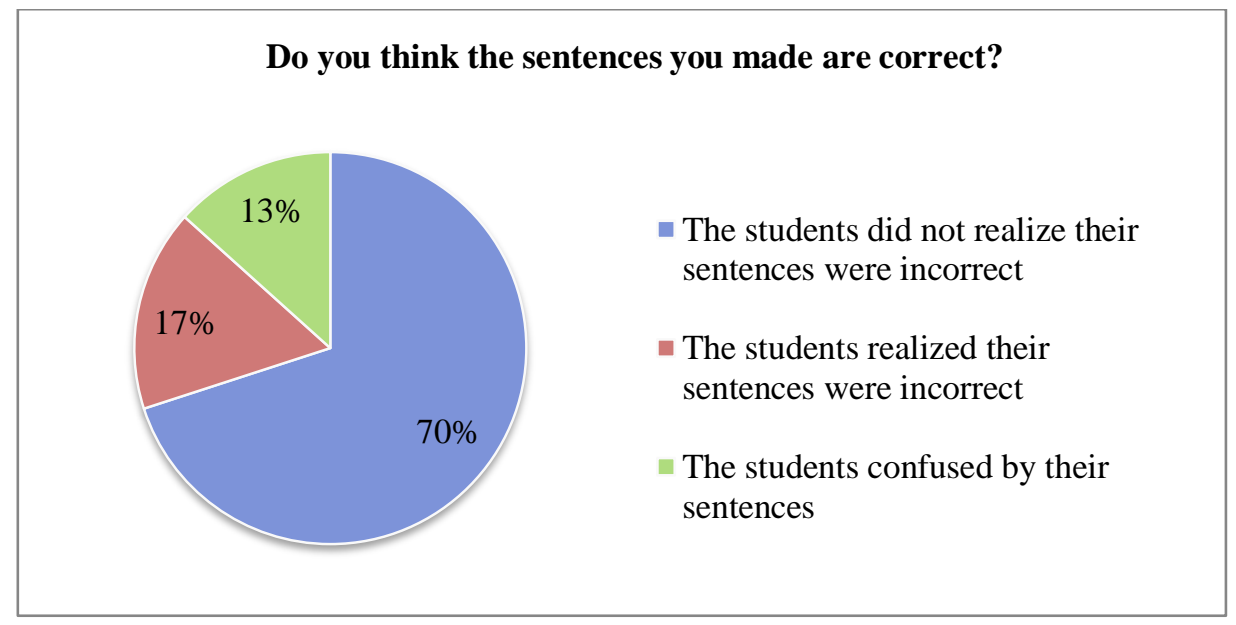

Figure 6. Results of Questionnaire related to

Students' Awareness of Committing Errors.

\section{Discussions}

Specifically, this section discussed the findings of this recent study. It reveals how the learners made errors in regard with elements of grammar and how their errors could be classified into certain types of errors belonged to Communicative Effect Taxonomy. To understand how those points could be answered, the discussion below extends the case. 


\section{Students' Grammatical Errors in Terms of Communicative Effect Taxonomy}

The findings of this study revealthat the students make errors in forms of global and local errors in terms of Communicative EffectTaxonomy. In Table 1, it can be observed that the local errors are most committed by the students than global errors. It turns out that this finding supports some related studies, such as done by Rosanti (2019). She also found that the students made more local errors than global errors in their translations which were also found in the researcher's. Therefore, it can be inferred that the students' understanding of how to construct grammatically correct sentences is still limited, but the sentences they produce are still understandable to the reader.To know further error types made by the students in terms of Communicative Effect Taxonomy, the discussion below shows the case.

\section{Local Error}

Based on Table 1 shown above, the local error becomes the highest rate. It means that the students mostly committed local errors in their translation. Dulay, et al(1982) state that local error tends to only affecta single element or constituent in a sentence and does not affect the structure and the meaning of whole sentence. The students mostly made local error in relation to the use of verbs and articles. They often made misformation of verbs and omission of articles in their translation. The following is one of the students' erroneous sentences as an example to show the case:

\section{TL: We taked some picture at there. \\ SL: Kami mengambilbeberapafotodisana.}

In the examples above, the students failed to use an appropriate verb and quantifier forms. The verb takedshould be changed into took because it tells past event. The most frequent error aspect dealt with verb inflection. Although the students made many errors, their recount texts could still be understood by the readers. The incorrect sentence should be revised as We took some pictures there.

\section{Global Error}

Table 2 shows that the amount of global error is lower than the total of local errors students made in their translation. Dulay, et al (1982) point out that the global error can affect overall sentence organization then significantly hinder communication. To know what the global error the students made, the example below shows the case:

TL: We don't swim if it's not dangerous and just play in the sand near the beach.

SL: Kami tidakberenangkarenaombak yang berbahayadanhanyabermainpasir di dekatpantai.

In the example above, the student made grammatical errors and semantic errors which can mislead the readers. The student used the wrong connector 'if' to express cause and effect sentence. Besides being grammatically incorrect, the sentence is also semantically illogical.This kind oferror can affect the sentence structure and meaning, hinderingcommunication and 
making the readers misinterpret the sentence. Consequently,the sentence should be revised as We did not swim because the waves were dangerous and just played in the sand near the beach.

\section{Causes of Students' Errors}

After getting the questionnaires that the students had been answered, it could be concluded that there were five possible causes of students' errors. They were problems in the target language, mother-tongue interference, lack of eagerness to learn the target language, lack of confidence, and the absence of error feedback from the teacher.This finding confirmed some previous studies related to the causes of errors. Cúc (2018)found mother-tongue interference and the lack of knowledge of the target language as the possible causes of students' translation error. AlKhairy (2018) stated that the students need guidance from their teacher to help them minimize the errors and motivate them to be more active in learning English. Those causes of errors are further discussed in the following discussion.

\section{Problems in the Target Language}

After coding the data of the questionnaires that the students had been answered, it could be concluded that students had difficulties in writing English such as difficulty in vocabulary, tenses, and grammar. From the results of students' answers, most of students stated they did not know a lot of English vocabulary, which led them to need extra time when making the sentence. In addition, the students are not familiar with the sentences appropriately. Hence, the students overgeneralized the rules or made their own rules of the target language because of their inability to differentiate between the source and target language rules.

\section{Mother-tongue Interference}

This interference made errors in the students' translation because they used their first language linguistic knowledge rather than the target text linguistic knowledge. The students may assume that the target language and their first language are similar. Since there were some differences between the source text and the target text, it made the errors happen. In translating the text, the students applied word by word translation using their first language structures.

\section{Lack of Eagerness to Learn the Target Language}

In learning to write English, almost half of them stated they only learned from what was given by the teacher and the textbook in the school.It indicates that students did not have any will to explore learning the target language to improve their writing skills. This finding deals with Nik, Sani, et al. (2010), who found that students' errors happened due to the unmotivated students to improve their writing.

\section{Lack of Confidence}

The students admitted their low proficiency and limited vocabulary in translating the text. They felt that the translation tasks were difficult. They did not believe in their ability to perform the tasks well and did not put enough effort into the tasks. This result was similar to the previous research done by Wongranu (2017), which showed that carelessness, including misreading, low self-confidence, and students anxiety were the causes of error. 


\section{The Absence of Error Feedback from the Teacher}

The lack of teacher guidance by providing error feedback also plays an important role in improving students' writing skills. The questionnaire showed some of the students answered that their teachers did not provide any writing error feedback to them. Thus, the students always make the same error continuously since they did not know the correct answer.

\section{CONCLUSIONS AND SUGGESTIONS}

In relation to the result of the research, most of the students still committed all error types of Communicative Effect Taxonomy in recount text translation; local errors and global errors. Local errors were more dominant than global errors. This means that most of the students made errors in a single element of the sentences or mostly errors did not fully affect the whole meaning of the sentences. The frequencies of each type of error could be seen in the result chapter.The possible causes of errors that students committed in their translation were problems in the target language, mother-tongue interference, lack of eagerness to learn the target language, lack of confidence, and the absence of error feedback from the teacher.

Based on the conclusion above, the researcher proposes a suggestion concerning the research finding as follow; first, the researcher suggests the English teachers to encourage and motivate students to be more active in learning English by increasing students' exposure to all four English skills with specific emphasis on writing, then show the students' errors to make them no longer make similar errors, and invite them to do peer-correction to improve their knowledge. Second, the researcher suggests to the other researchers to analyse error using the other taxonomies i.e. Surface Strategy Taxonomy, Linguistic Category and Comparative Analysis Taxonomy. Third, since this study used questionnaire, the researcher suggests the other researchers to add some more items in the questionnaire that the researcher made by referring to the theory of error causes to obtain richer data and use other methodology which does not only consist of a questionnaire.

\section{REFERENCES}

Al-Khairy, M. A. (2013). Saudi English-major undergraduates' academic writing problems: A taif university perspective. English Language Teaching, 6(6), 1-12.

Anjarani, D. R., \& Indahwati, R. (2019). An analysis of students' errors in using simple past tense in translating narrative text. Prosodi, 13(2), 68-74.

Brown, H. D. (2001). Teaching by principles: An interactive approach to language pedagogy (2nd ed.). New York: Addison Wesley Longman.

Cúc, P. T. (2018). An analysis of translation errors: A case study of Vietnamese EFL students. International Journal of English Linguistics, 8(1), 22-29.

Dang, T. N. A. (2019). EFL student's writing skills : Challenges and remedies. IOSR Journal of Research \& Method in Education, 9(6), 74-84.

Dulay, H., Burt, M., \& Krashen, S. (1982). Language two. New York: Oxford University Press. 
Khoirunida, S. (2019). An analysis of grammatical errors in the translation made by the fourth semester students of English Education Program. JELLT (Journal of English Language and Language Teaching), 3(2), 114-125.

Koman, H. N. N., Hartono, R., \& Yuliasri, I. (2019). Translation errors in students' IndonesianEnglish translation practice. English Education Journal, 9(2), 206-218.

Kumala, B. P., Aimah, S., \& Ifadah, M. (2018). An analysis of grammatical errors on students' writing. 2nd English Language and Literature International Conference (ELLiC), 2, 144-146.

Nik, Y. A., Sani, B. B., Kamaruzaman, M. N. B. W. C., Hasbollah, H. R. B., et al. (2010).The writing performance of undergraduates in the University of Technology, Mara, Terengganu, Malaysia. Journal of Languages and Culture, 1(1), 8-14.

Rosanti, V. (2019). An analysis of grammatical errors on students' translation from Indonesian into English made by the second grade students of SMA N 1 Seputih Raman. Bandar Lampung: Lampung University.

Wongranu, P. (2017). Errors in translation made by English major students: A study on types and causes. Kasetsart Journal of Social Sciences, 117-122. 